\title{
Design of Structured Electrode for High Energy Densified and Fast Chargeable Lithium Ion Batteries
}

\author{
Sujin Park and Chang-Jun Bae ${ }^{\dagger}$
}

3D Printing Materials Center, Korea Institute of Materials Science (KIMS)

Changwon, Gyengnam, 51508, Republic of Korea

\section{전극구조설계 기반 고에너지밀도 · 고속충전 리튬이온배터리 제작}

\author{
박수진, 배창준 ${ }^{\dagger}$ \\ 재료연구소 3D프린팅소재연구센터
}

(Received December 3, 2018; Revised December 18, 2018; Accepted December 18, 2018)

\begin{abstract}
s
Lithium ion batteries have been widely adopted as energy storage and the LIB global market has grown fastest. However, LIB players have struggled against maximizing energy density since commercial monolithic electrodes are limited by electrolyte depletion caused by long and tortuous Li-ion diffusion pathways. Recently, new strategies designing the structure of battery electrodes strive for creating fast Li-ion path and alleviating electrolyte depletion problem in monolithic electrodes. In this paper, given the fundamental and experimental approaches, we compare the monolithic to structured electrodes and demonstrate the ways to fabricate high energy, fast chargeable Lithium ion battery.
\end{abstract}

Keywords: structured electrode, lithium ion battery, high energy density

\section{1. 서론}

산업혁명 이후 무분별한 화석연료의 사용으로 오존층 이 파괴되고 기온상승, 이상기후 현상, 해류 변화 등 수 많은 환경문제가 발생하고 있다. 2017년 세계보건기구는 600 만 명 이상이 대기오염에 노출돼 사망한 것으로 집계 했으며 이처럼 환경오염의 심각성이 대두함에 따라 세계
각국은 이산화탄소 배출 등 환경 규제 강화와 더불어 대 체 에너지 개발에 박차를 가하고 있다. 다양한 대체 에너 지원 중 리튬이온전지는 친환경성, 높은 에너지밀도와 에 너지 저장 효율의 장점들로 인해 전기자동차부터 에너지 저장장치(ESS)에 이르기까지 일상생활 곳곳에서 다양하 게 사용되며 그 활용도를 넓혀가고 있다. 특히 전기차, 드 론, 사물인터넷 등과 관련된 4 차 산업혁명의 핵심 동력원 
으로 주목을 받으며 최근 고에너지밀도의 리튬이온전지 의 개발을 위한 연구가 활발히 진행되고 있다. ${ }^{1)}$

고에너지밀도를 갖는 리튬이온전지 개발을 위해 소재 적 접근을 통한 새로운 활물질 개발과 구조적 접근을 통 한 단위면적당 활물질 양을 증가시키는 연구들이 진행 중 이다. 소재적 접근은 더 높은 이론용량을 갖는 새로운 소 재의 합성 또는 기존 소재의 표면처리를 이용한 배터리의 성능개선 등이 있다. 하지만 새롭게 개발된 신소재는 배 터리 안전성과 신뢰성 확보를 위해 5 년 이상의 필드테스 트를 반드시 통과해야 하므로 고에너지밀도가 시급히 필 요한 활용처에 적용하기 어려운 한계가 존재한다. 반면에 구조적 접근은 기존 신뢰성이 확보된 상용 소재를 기반으 로 단위면적당 활물질 양을 증가시켜 즉각 적용 가능하다 는 장점이 있다.

구조적 접근을 통한 고에너지용 리튬이차전지 개발은 기존 소재를 활용하여 바로 적용 가능한 현실적인 방법이 다. 하지만 상용화된 단순 구조의 전극에서 단위면적당 활물질의 로딩이 증가할 경우 에너지 밀도는 증가하지만, 배터리의 성능이 저하되는 문제점에 대해 이론적, 실험적 으로 보고되고 있다. 특히 에너지 밀도와 출력밀도 간의 상관관계는 전극이 두꺼워질수록 더욱 뚜렷하게 나타나 게 된다. 이는 리튬이온 이동 거리가 전극 내부 구조의 tortuosity factor에 의해 영향을 받기 때문이다. 단위면 적당 활물질의 양이 증가할수록 tortuosity가 증가하여 리튬이온의 이동거리가 증가하고 확산속도가 감소하게 된다.

이러한 문제점을 해결하기 위해 리튬이온 확산 속도를 개선하고 에너지와 출력 간 상호 영향을 최소화하기 위한 전극 구조 제어 연구가 활발히 진행되고 있다. 전극구조 를 3 차원의 그물망 형태로 연결된 기공 구조로 설계할 경 우 두꺼운 전극에서도 리튬이온의 빠른 이동 통로를 제공 하여 고성능의 고에너지밀도의 전극을 구현할 수 있다. 본 기고에서는 이러한 전극 구조 제어를 통한 고에너지밀 도의 배터리성능향상에 대해 수식기반의 이론적 접근과 실제 전극 내 기공을 형성하기 위한 실험적 접근에 대해 기술하고자 한다.

\section{2. 본론}

\section{1 수식접근을 통한 고에너지용 단순구조 전극의 한계 규명}

리튬이온전지로 구동되는 전기자동차 상용화를 위해 시급히 필요한 핵심 기술은 장거리 주행을 위한 고에너지 밀도와 충전시간 단축을 위한 고속충전 특성이 동시에 요 구되지만 현 단순구조 전지의 딜레마는 에너지와 파워 간 의 상충관계(Trade-off Relation)에 있다. 현재 이차전 지 시장에서는 $3.5 \mathrm{mAh} / \mathrm{cm}^{2}$ 이상의 용량을 갖는 전극을 고에너지용 양극 전극으로 평가하고 있으며, 이를 제작하 기 위하여 전극을 두껍게 쌓아 활물질 양을 늘리고 비활 물질인 집전체, 바인더, 분리막의 양을 감소시켜 실제 부 피당 에너지 밀도를 증가시키고 있다. 그러나, 이차전지 성능은 단위면적당 활물질의 양이 증가할수록 전극 내부 의 tortuosity가 증가하여 리튬이온의 농도구배가 생기 고 전극내 저항이 증가하게 된다.

미국 캘리포니아 버클리 대학의 John Newman 교수 연구진은 최초로 전류밀도 증가에 따른 이온농도구배를 수식으로 증명하여 이를 뒷받침 하였다. ${ }^{2)}$ Capacity vs. rate과 energy vs. power 간의 상관관계 증명을 위해 단 일 전극 내부에서의 macroscopic transport를 $1 \mathrm{D}$ 로 가 정하여 전극 내부에서의 전류와 전압에 대한 수식기반을 통해 규명하였다. Fig. 1(a), (b)는 모델 수식으로서 half-cell 내부를 나타내는 전극 모식도와 전극 두께와 방전 전류 밀도(방전속도)에 따른 리튬 이온 농도 구배에 대한 상관 관계를 나타내고 있다. Fig. 1(b)에서 수평방향 (a)

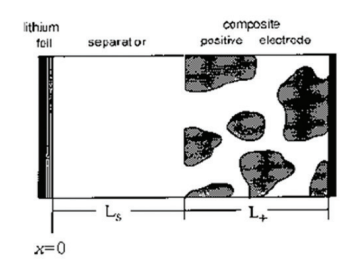

(b)

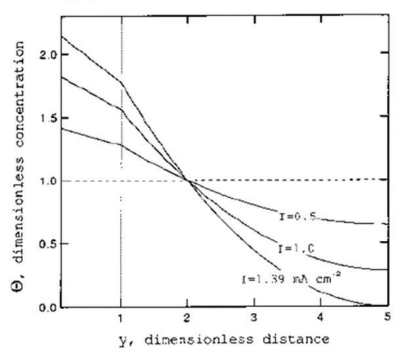

Fig. 1. (a) macroscopic transport를 $1 \mathrm{D}$ 로 가정한 전극 모델 (b) 전류 밀도와 전극 두께에 따른 리튬이온농도구배 


\section{특 집 ㅁㅃ 박수진, 배창준}

(a)

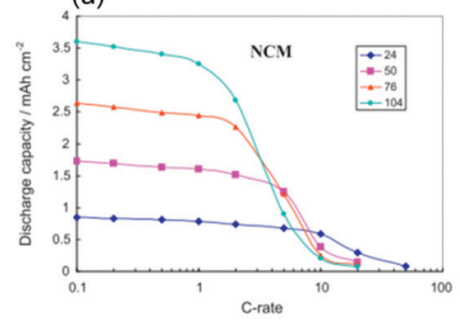

(b)

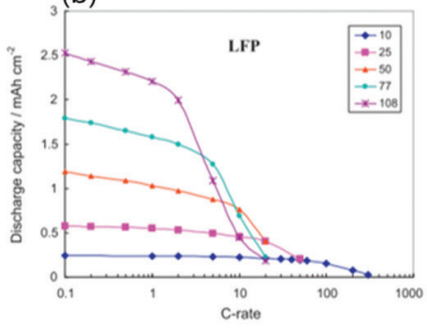

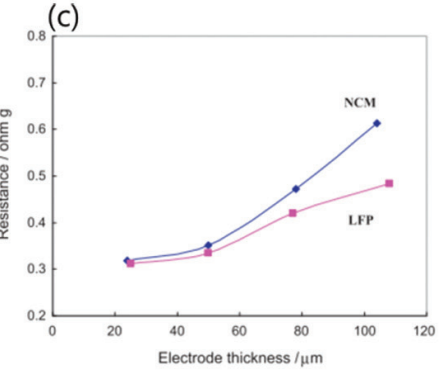

Fig. 2. (a), (b) 전극두께와 c-rate에 따른 NMC와 LFP의 방전용량 (c) 전극두께에 따른 전극내부저항

점선들은 방전 시작 전 초기에는 분리막과 양극 전극 내 리튬이온 농도가 균일하여 농도 구배에 의한 배터리 내 저항이 존재하지 않음을 나타내며 그래프에서의 실선은 0.5 에서 $1.39 \mathrm{~mA} / \mathrm{cm}^{2}$ 의 전류밀도를 나타낸다. 방전이 시작되고 기울기가 증가함은 전극 내 큰 전류밀도가 가해 짐에 따라 분리막과 전극 내 리튬이온농도 구배가 심해짐 을 나타내고 있으며 농도차에 의한 큰 저항이 생성되게 된다. 특히 $1.39 \mathrm{~mA} / \mathrm{cm}^{2}$ 전류 밀도에서는 집전체에 맞 닿은 부분, 즉 전극의 표면에서 멀어질수록 리튬이온의 농도 구배가 커지며 전해질 내 리튬이온 결핍 현상이 발 생하여 저항이 급속하게 증가하여 리튬이온은 존재하나 배터리 구동에 참여하지 못하는 dead zone이 된다. 이 연구는 두꺼운 상용 단순 전극 내 이온농도구배가 발생하 고 이로 인해 저항이 증가함을 수식으로 증명하여 전극 구조 제어의 필요성을 보여준 최초의 연구이다.

중국 Soochow대학 Zheng 교수 연구진은 다양한 두께 의 NCM과 LFP 전극을 충방전 속도에 따른 에너지밀도, 출력밀도, 수명 등 전기화학성능을 분석하고 두꺼운 전극
에서 출력성능이 떨어지는 주원인을 리튬이온확산으로 규명하였다. ${ }^{3)}$ Fig. 2(a)와 (b)는 다른 두께를 갖는 NCM 과 LFP 기반 전극의 방전속도 $(\mathrm{C}-$ rate $)$ 에 따른 방전용량 을 나타내고 있다. 두 양극 모두 느린 방전속도인 $0.1 \mathrm{C}$ 에 모든 두께에서 최대 방전용량값을 냈으나 빠른 c-rate 구간에서는 전극이 두꺼워 질수록 급격한 방전용량 감소 를 보였다. 방전속도와 전극 두께 간 상관관계를 나타내 기 위하여 $0.1 \mathrm{C}$ 에서 갖는 최대 방전용량 대비 약 $70 ~ 80 \%$ 방전용량을 갖는 지점을 최대 방전속도로 가정하였다. $25 \mathrm{um}$ 두께를 갖는 NCM와 LFP 전극의 최대 방전속도 는 $10 \mathrm{C}$ 와 $20 \mathrm{C}$ 였지만 두께가 $100 \mathrm{um}$ 로 증가할 경우 $\mathrm{NCM}$ 과 $\mathrm{LFP}$ 전극 모두 약 $2 \mathrm{C}$ 부근에서 급격한 용량 감 소를 보였다. Fig. 2(c)는 전극 두께, 즉 단위면적당 활물 질의 로딩레벨에 따른 weight specific impedance (WSI)를 나타내며, 이를 통해 전극의 두께가 증가할수록 전극 내부 저항이 증가함을 증명하였다. LFP가 NCM 보 다 더 낮은 저항을 나타내는 이유는 LFP의 표면적이 $\left(15.4 \mathrm{~m}^{2} / \mathrm{g}\right) \mathrm{NCM}$ 에 $\left(0.4 \mathrm{~m}^{2} / \mathrm{g}\right)$ 비해 훨씬 크기 때문이 (a)

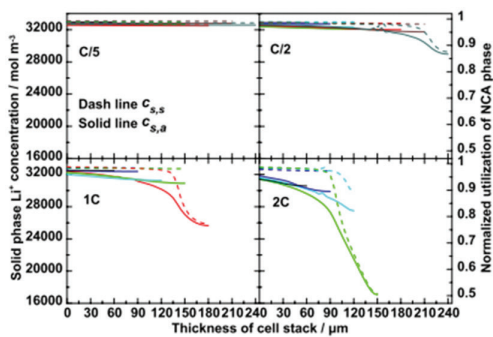

(b)

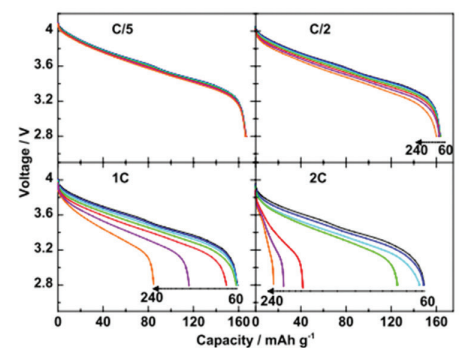

Fig. 3. 전극두께와 c-rate에 따른 (a) 입자 표면의 리튬이온농도와 평균 리튬이온농도 (b) 방전 특성 
다. 이 결과는 단순구조의 전극에서 단위면적당 활물질의 로딩레벨이 높을 때 나타나는 전기화학적 특성 열화를 전 극 내부 저항 증가를 통해 뒷받침하여 고에너지용 단순구 조 전극의 성능 저하에 대한 포괄적인 이해를 돕는 의미 있는 연구이다.

미국 Oak Ridge National Lab의 Zhijia Du 연구진은 $\mathrm{NCA}$ 흑연 전지에서 에너지밀도와 출력밀도의 최적화를 위해 수식기반 모델링을 진행하였다. ${ }^{4)}$ 전극 두께에 따른 전극 성능을 COMSOL기반 시뮬레이션을 통해 나타내고 다양한 충방전 속도에 따른 critical thickness를 증명하 였다. Fig. 3(a)의 점선은 NCA 분말 표면의 리튬 이온 농 도를 나타내며 $\left(C_{s, s}\right)$ 실선은 방전 후의 $\mathrm{NCA}$ 파우더 전체 의 평균 리튬이온농도 $\left(C_{s, a}\right)$ 를 의미한다. 양극에서의 cutoff 전압은 $\left(C_{s, s}\right)$ 에 의해 결정되며 활물질의 utilization과 관련된 비용량은 $\left(C_{s, a}\right)$ 에 의해 결정된다. $\mathrm{C} / 5$ 에서는 모든 전극 두께에서 $\left(C_{s, s}\right)$ 와 $\left(C_{s, a}\right)$ 의 차이가 거의 나지 않으며 이는 Fig. 3(b)의 C/5에서 $60 \mathrm{um}$ $240 \mathrm{um}$ 의 전극두께에서 방전용량의 변화가 없는 결과와 잘 일치한다. 하지만 c-rate가 증가할수록 $\left(C_{s, a}\right)$ 는 점점 감소하는 현상을 보이는데 이는 높은 전류밀도에서 $\left(C_{s, s}\right.$ )가 포화 값으로 빠르게 증가하여 cutoff 전압에 도달하 기 때문이며 결국 $\left(C_{S, S}\right)$ 와 $\left(C_{s, a}\right)$ 의 차이가 활물질의 underutilization을 초래함을 알 수 있다. 본 연구는 단 위면적당 활물질의 로딩레벨이 높을수록 전극 내의 underutilization 증가와 분극화 유발을 증명하여 단순 한 전극구조에서의 고에너지밀도와 고속충전의 상충관 계를 뒷받침하였다.

이처럼 현재 단순구조의 전극은 고에너지밀도 구현을 위해 단위면적당 활물질의 로딩레벨을 높일수록 전극 내 의 분극화 유발, 활물질 utilization 영역 감소, 출력특성 저하 등의 문제점이 있다. 고에너지밀도에서 전기화학적 특성을 개선하기 위해서는 리튬이온의 확산속도 향상과 배터리내의 저항 감소 등의 문제가 해결되어야 하며 이러 한 문제는 전극구조의 개선을 통해 개선이 가능하다.

리튬이온의 확산 시간 $\left(t_{e q}\right)$ 은 확산 거리 $(L)$ 와 확산 계 수 $(D)$ 로 표현 할 수 있으며 실제 리튬이온의 이동거리인 확산거리 $(L)$ 는 tortuosity $(\tau)$ 와 집전체로부터의 전극의
두께(T)로 나타낼 수 있다.5)

$$
t_{e q} \propto \frac{L^{2}}{D}=\frac{(\tau \cdot T)^{2}}{D}
$$

따라서 고속충방전을 위한 빠른 리튬이온의 확산속도 를 확보하기 위해서는 확산거리를 줄이고 확산계수를 높 여야 한다. 확산계수의 경우 소재적 접근을 통해 향상 할 수 있으며 확산거리는 tortuosity와 전극두께를 감소시 켜 줄일 수 있지만 전극 두께가 감소할 경우 에너지밀도 가 낮아지게 된다. 따라서 확산거리의 감소를 위해서는 전극 구조 개선을 통해 tortuosity를 감소시켜 빠른 속도 로 이동 가능한 리튬이온의 이동 통로를 만들어야 한다. 특히 리튬이온의 확산시간은 확산거리의 제곱에 비례하 기 때문에 전극 구조 개선을 통해 고속충방전은 크게 향 상될 수 있다.

전극구조의 제어는 배터리의 내부 저항과도 밀접한 관련 이 있다. 배터리의 내부 저항은 $R_{b}=R_{e l}+R_{A, C}+R_{i n}(A, C)+R_{c}(A, C)$ 로 나타낼 수 있다. ${ }^{6)}$ 이때 $R_{e l}$ 는 전해액의 저항, $R_{A, C}$ 는 음 극과 양극 전극의 저항, $R_{i n}(A, C)$ 는 전해액과 음극/양극 계면에서의 리튬이온이동의 저항, $R_{c}(A, C)$ 는 음극과 양 극을 통해 집전체로 전달되는 전자의 저항을 의미한다. 전해액의 저항은 $R_{e l}=L / \sigma_{i} A$ 로 정의되며 최소 저항값 을 위해서는 얇은 전해액층 두께 $(\mathrm{L})$, 큰 전극 표면적 $(\mathrm{A})$ 및 높은 리튬 이온 전도도 $\left(\sigma_{i}\right)$ 가 요구된다. $R_{i n}$ 는 전해액 과 전극의 계면적이 넓을수록 감소한며 $R_{c}$ 는 다공성 전극 을 통해 집전체와 전극의 접촉이 잘 이루어 질수록 감소 할 수 있다. 이를 통해 배터리의 내부 저항과 관련된 모든 변수들은 전극구조 제어를 통해 최소화 할 수 있음을 알 수 있다.

\section{2 전극구조 제어를 통한 고에너지밀도, 고속충방전 전극의 구현}

전기화학적 성능 향상을 위한 전극구조 제어는 꾸준히 연구되어 왔으며 최근 3 차원 구조로 제작된 전극들이 고 에너지밀도, 고속충방전 성능을 보이는 연구결과들이 보 고되고 있다.

미국 Illinois Urbana-Champaign 대학의 Braun 교 수 연구진은 electropolishing과 electrodeposition 공 
(a)

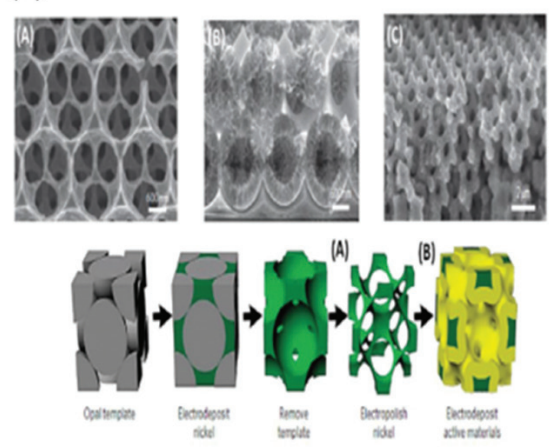

(b)

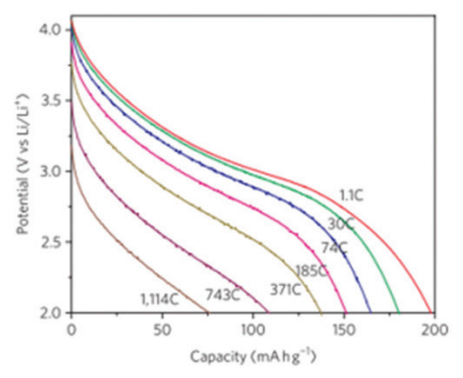

Fig. 4. (a) 템플릿을 이용해 제작한 다공성 전극구조 (b) 3차원기공구조 전극의 c-rate에 따른 방전곡선

정을 적용하여 고속 충방전이 가능한 3차원 구조 $\mathrm{MnO}_{2}$ 양극을 보고하였다(Fig. 4a). ${ }^{7}$ 전극 내부의 저항을 최소 화하여 고속충방전 특성을 확보하기 위해 전해액 내 이온 이동, 전극 내 이온 이동, 전극 내 전기화학적 반응 및 전 극과 집전체 간 전기전도도를 고려하여 전극구조를 설계 하였다. 전해액 내 빠른 이온 이동속도를 위해 닫힌 기공 이 없는 전해액으로 채워진 연결된 열린 기공 네트워크를 고려하여 전체 기공률을 $\mathrm{FCC}$ 구조의 템플릿에서의 최대 이론값인 $96.4 \%$ 에 근접한 $94 \%$ 까지 증가시켰다. 또한, 전극 내 이온 확산속도 향상을 위해 확산거리를 최소화하 고 전극 표면적 증가 및 높은 전자전도도를 갖는 전극 구 조를 설계하여 위에서 언급된 4가지 메커니즘과 관련된 저항을 최소화하여 $1114 \mathrm{C}$ 에서도 구동하는 전극을 개발하 였다. 연결된 기공 구조의 전극을 이용하여 두꺼운 전극 에서도 전기화학적으로 utilization 되는 범위를 넓혔으 며 고속충방전 특성을 향상시킨 의미있는 연구이다.
미국 MIT 대학의 배창준 박사와 Yet-Ming Chiang 교수는 dual-scale 기공을 통해 전극 내 tortuosity를 최 소화하여 이온 이동속도, 전극의 kinetic을 향상시키고 전극의 출력을 최대화한 연구결과를 보고했다.8) 단순구 조 전극 경우에는 전극밀도가 증가함에 따라 tortuosity ( $\tau)$ 는 비선형적으로 증가함을 아래 Bruggeman relationship을 통해 나타내었고 주어진 전극 두께와 기공률 ( $\varepsilon$ )에서 출력특성을 최대화 할 수 있는 전극 구조를 설계 하였다.

채널 설계의 최적화를 위해 소결된 세라믹 기공율인 $\varepsilon=0.15 \sim 0.5$ 에 해당하는 1.5 를 $\gamma$ 의 값으로 사용하였다. Fig. 5(b)는 전극의 기공율 $(P)$ 이 0.36 으로 일정할 때 전 극의 두께(T)에 대한 채널간의 거리( $\lambda$ )인 $\lambda / T$ 와 전극 전 체의 기공율에 $(P)$ 대한 채널의 기공율 $\left(P_{c}\right)$ 인 $P_{c} / P$ 에 따른 tortuosity를 나타낸다. 주황색은 $\tau_{e f f}=2.4 \sim 2.6$, 노란 색은 $20 \%$ 감소한 $\tau_{e f f}=2.0$, 초록색은 제작 가능한 기공 (a)

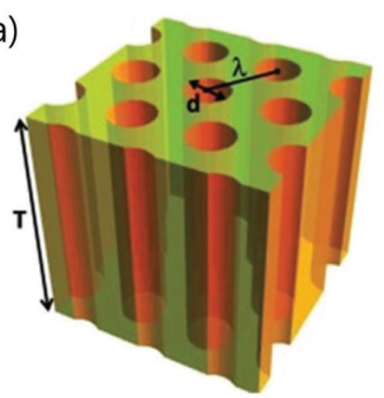

(b)

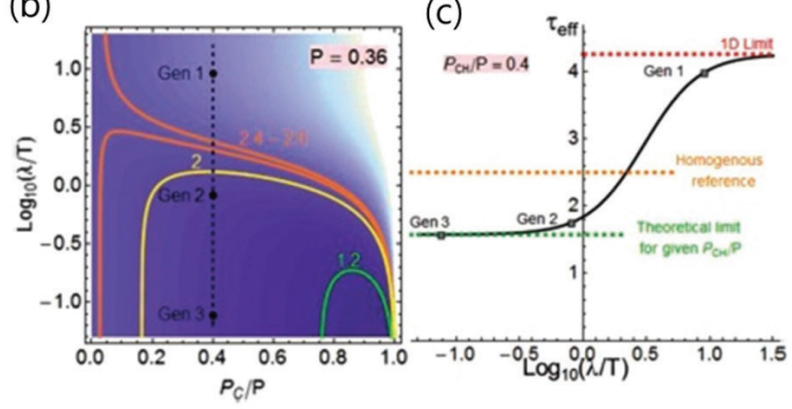

Fig. 5. 전극의 두께와 채널간의 거리, 채널의 기공율에 따른 tortuosity 
(a)

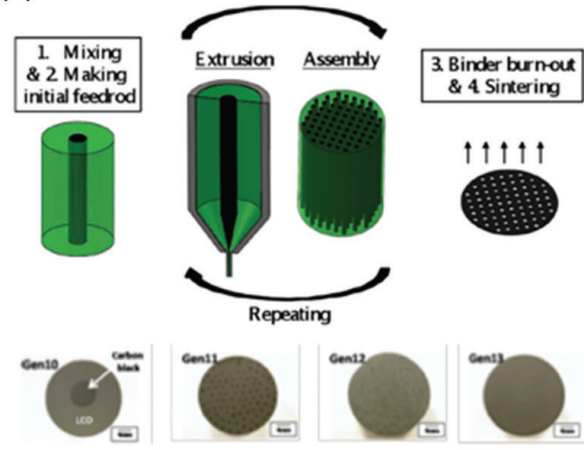

(b)

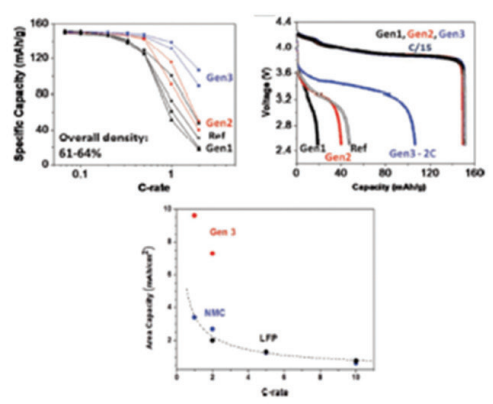

Fig. 6. (a) 다공성 전극구조 제작을 위한 공정 과정 (b) 다공성 전극의 전기화학적 특성

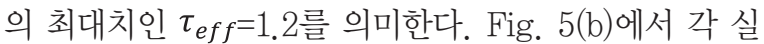
선을 기준으로 윗부분은 높은 tortuosity 값을 가지며 오 른쪽 아랫부분에 위치한 $\tau_{e f f}=1.2$ 를 갖는 초록색 실선은 채널 간 거리인 $\lambda$ 가 짧기 때문에 많은 채널이 존재함을 의미한다. Fig. 5(c)는 tortuosity와 채널간의 거리에 대 한 이해를 돕기 위해 Fig. 5(b)에서 $P_{c} / P=0.4$ 인 지점을 다시 나타낸 것으로 Gen1에서 Gen3로 갈수록 채널 간 거리인 $\lambda$ 가 짧아짐을 의미한다. 1D limit 상한선은 매트 릭스와 채널까지 확산길이가 너무 길기 때문에 effective tortuosity 값이 크게 되고 전해질 결핍이 매트릭스 내에 서 일어나기 때문에 느린 리튬 이온 이동 속도를 보이나 하한선은 매트릭스와 채널까지 확산 거리가 짧기 때문에 effective tortuosity 값이 작고 채널을 통해 확산이 원활 하여 빠른 리튬 이온 이동 속도를 가능케 함을 나타낸다.

Tortuosity가 배터리의 특성에 미치는 영향을 확인하 기 위해 복잡한 계면을 최소화하여 활물질에 대해서만 고
려하고 에너지 밀도를 최대화하고자 co-extrusion과 assembly 공정을 반복해 제작된 Gen 1, 2, 3 전극은 소 결과정을 통해 카본과 바인더를 제거하였다(Fig. 6(a)). Fig. 6(b)는 Gen 1, 2, 3에 대한 전기화학평가를 보여주 며 Gen 3이 단순구조의 기준전극보다 2 3배 이상의 용 량을 냄을 확인할 수 있다. 뿐만 아니라 대부분의 모바일 기기나 전기차에 적용되는 $2 \mathrm{C}$ rate에서 $\mathrm{Gen} 3$ 은 기존 보고된 전극과 비교해 3 배 이상의 단위면적당 용량을 보 였다.

한편 양극뿐만이 아니라 음극 전극에서도 전극구조 제 어를 통한 성능개선을 위한 활발한 연구가 진행되고 있 다. 국내의 카이스트 강정구, 김용훈 교수 공동연구팀은 화학기상증착법을 이용하여 3차원 그물형상의 그래핀을 제조하고 그 위에 $6 \mathrm{~nm}$ 크기의 메조 기공이 형성된 이산 화 티타늄 나노입자 박막을 입혀 복합구조체를 이용하여 (Fig. 7(a)) 1 분이면 $130 \mathrm{mAh} / \mathrm{g}$ 의 용량을 완전 충전 할 (a)

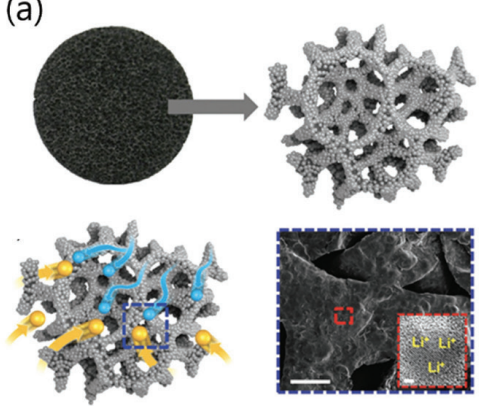

(b)
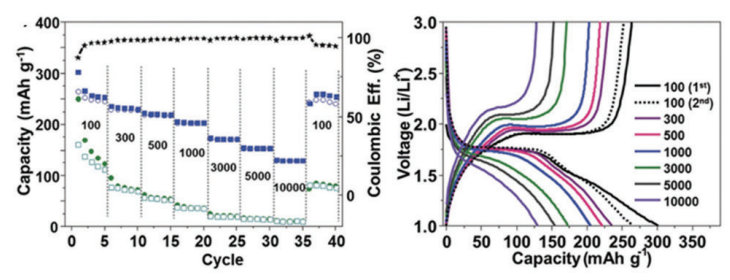

Fig. 7. (a) 3차원 그물형상의 기공형태 전극 (b) 다공성 전극의 전기화학적 특성 
수 있고 15 분이면 현재 사용하는 스마트폰을 완전 충전 할 수 있는 전극을 개발하였다. ${ }^{9}$ 크기가 작은 나노 입자 를 사용하여 표면부터 중심까지 거리가 짧아 리튬이온이 동통로를 제공하여 멀티구조의 고속충전이 가능성을 확 인할 수 있는 연구이다. Fig. 7(b)는 복합구조체의 고속 충방전 결과를 보여준다. 이 연구를 통해 전극구조뿐만이 아니라 바인더를 사용하지 않아 바인더 없이 집전체에 3 차원 그물형상의 메조 기공 그래핀이 바로 연결되어 계면 저항이 낮으며 더욱 우수한 전기화학특성을 나타내어 $100 \%$ 에 가까운 효율을 10,000 싸이클까지 확보하였다. 또한 리튬이온 확산에 필요한 활성화에너지를 계산하여 전극구조 제어를 통해 리튬이온확산속도를 향상시킬 수 있음을 증명하였다. 리튬이온확산을 위한 활성화에너지 는 Butler-Volmer 식과 아레니우스 수식을 이용하여 아 래와 같이 표현할 수 있다. ${ }^{10)}$

$$
i_{0}=\frac{R T}{n F R_{c t}}=A \exp \left(-\frac{E_{a}}{R T}\right)
$$

$i_{0}$ 는 교환전류, $n$ 은 반응에 참여하는 전자의 수, $F$ 는 패 러데이상수, $R_{c t}$ 는 charge transfer 저항, $R$ 은 gas constant를 의미한다. 이 수식을 기반으로 3 차원 연결된 기공의 전극구조를 가진 $\mathrm{TiO}_{2}$ 전극의 활성화에너지는 $0.36 \mathrm{eV}$ 로 단순구조의 $\mathrm{TiO}_{2}$ 전극의 활성화에너지 0.56 $\mathrm{eV}$ 에 비해 낮은 리튬이온확산을 위한 활성화에너지를 보 였다. 또한, 리튬이온의 Diffusivity (D)는 다음과 같이 표현할 수 있다.

$$
\mathrm{D}=\frac{R^{2} T^{2}}{2 A^{2} n^{4} F^{4} C^{2} \sigma^{2}}
$$

이때 $\mathrm{A}$ 는 전극의 표면적, $\mathrm{C}$ 는 벌크 농도를 의미하며 그 물형상의 연결된 기공 구조의 $\mathrm{TiO}_{2}$ 전극의 Diffusivity는 $1.40 \times 10^{-14} \mathrm{~cm}^{2} \mathrm{~S}^{-1}$ 로 단순구조 전극의 Diffusivity 인 $2.94 \times 10^{-16} \mathrm{~cm}^{2} \mathrm{~S}^{-1}$ 에 비해 훨씬 높은 값을 보였 다. 이처럼 전극 구조 제어를 통해 제작된 음극 전극은 낮 은 활성화에너지와 높은 Diffusivity를 바탕으로 빠른 리 튬이온 확산을 보이며 단순구조 전극에 비해 향상된 rate 특성을 나타냄을 알 수 있다.

다양한 템플릿을 합성하여 3 차원 전극구조를 만드는 연구 외에도 나무, 규조 등 bio 템플릿을 이용하여 멀티

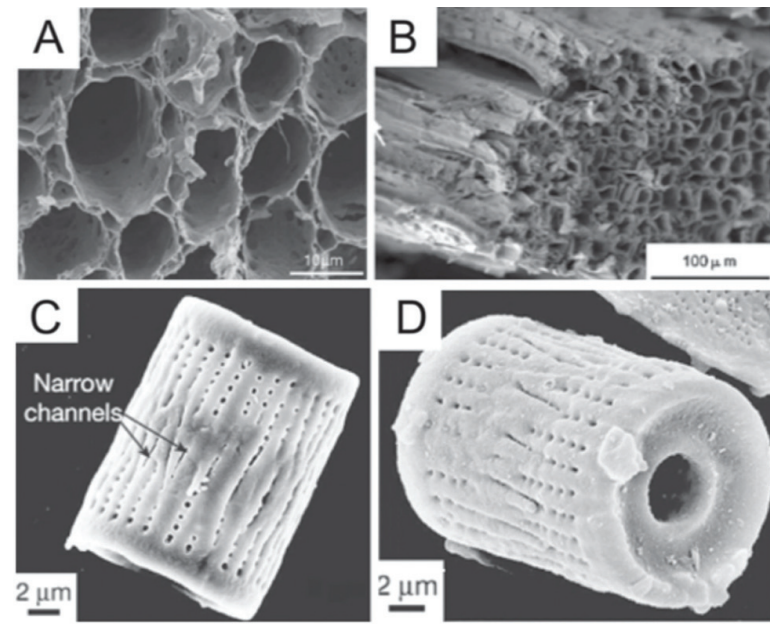

Fig. 8. 나무를 다공성 전극 템플릿으로 활용한 예시

전극구조를 만드는 연구도 진행중이다. Fig. 8은 bio 다 공성 템플릿을 전극으로 활용한 예시를 보여준다.11) 예를 들어 나무를 전극 구조 템플릿으로 사용하여 나무 내 물 과 미네랄의 운반 통로였던 가도관상세포가 전극에서는 리튬이온의 이동통로로 적용될 수 있다. 나무는 열처리를 통해 탄소로 전환되기 때문에 리튬이온전극에서 더욱 유 용하게 사용될 수 있으며 자연친화적이다. 현재까지 $\mathrm{TiO}_{2}, \mathrm{NiO}, \mathrm{Mn}_{2} \mathrm{O}_{3}$ 소재가 나무 템플릿을 이용하여 제작 되었으며 모두 연결된 기공 구조의 미세구조를 나타냈다. 아직까지 나무를 이용한 전극 구조에 대한 전기화학적 특 성 향상은 정확히 규명되지 않았으나, 고속충방전 전극을 위해 많은 주목을 받고있다.

\section{$2.33 \mathrm{D}$ 프린팅 기반 3차원 전극의 구현}

3 차원 전극 구조를 통해 전기화학성능이 향상되고 연 결된 기공 네트워크를 갖는 전극 구조를 제작하기 위해 템플릿 합성 또는 압출 공정 등 다양한 공정 방법에 대한 연구가 보고되었지만 상용화 하기에 지나치게 복잡하다 는 한계를 갖고 있다. 한계점 극복을 위한 해결책 중 하나 는 $3 \mathrm{D}$ 프린팅 공정 도입을 고려할 수 있다. 하지만 $3 \mathrm{D}$ 프 린팅을 이용한 전극 구조 제어는 템플릿을 이용한 전극 구조에 비해 많이 보고되어 있지 않으며 특히 전극구조 설계를 통한 전기화학 성능 향상에 대한 연구는 거의 진 행되지 않은 연구 초기 단계이다. 
(a)

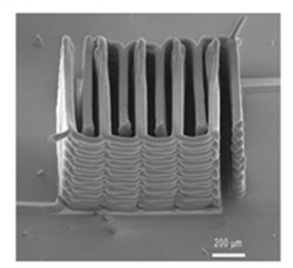

(c)

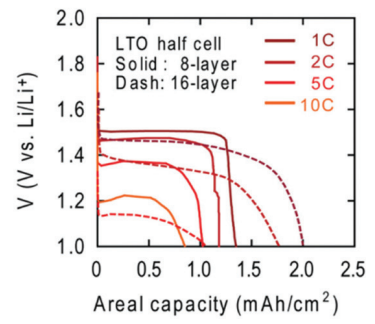

(b)

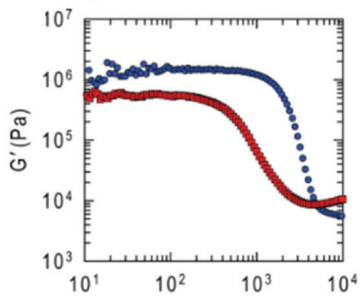

(d) Shear stress $(\mathrm{Pa})$

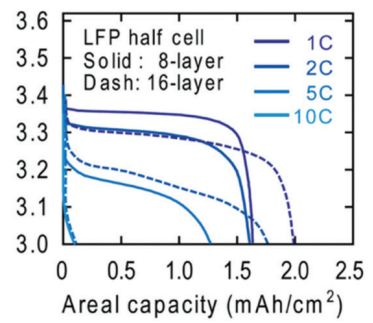

Fig. 9. (a) 3D프린터를 이용해 제작한 마이크로배터리의 SEM 이미 지 (b) 3D프린팅용 배터리 잉크의 점도 (c), (d) 제작된 마이 크로 배터리의 전기화학적 특성

미국 Illinois Urbana-Champaign대학 제니퍼 루이 스 교수 연구진은 사람 머리카락보다 가는 $30 \mathrm{um}$ 두께의 배터리 잉크를 정교하게 프린팅 하여 소형 배터리 전극을 $3 \mathrm{D}$ 프린터로 제작하여 출력하는데 성공하였다. ${ }^{12)}$

Fig. 9(a)는 3D프린터를 이용해 제작한 마이크로배터 리의 $\mathrm{SEM}$ 이미지를 보여준다. 마이크로 $3 \mathrm{D}$ 프린팅 전극 제작을 위해 이 연구에서는 건조와 열처리 후에도 정교한 라인을 유지하고자 조성과 잉크 점도의 최적화를 진행하 였다. ${ }^{[13]}$ 정밀도 향상을 위해 잉크를 만들기 전 모든 분말

은 원심분리기를 이용해 $300 \mathrm{~nm}$ 이상의 크기를 갖는 입 자를 모두 제거하여 노즐이 막히는 현상을 방지하였으며, $\mathrm{LTO} 57 \mathrm{wt} \%$, LFP $60 \mathrm{wt} \%$ 의 조건에서 3D프린팅에 적 합한 점도인 shear rate $1 \mathrm{~s}^{-1}$ 에서 $10^{3} \sim 10^{4}$ 의 점도를 나 타냄을 확인하였다. Fig. 9(b)는 점성뿐만이 아니라 잉크 의 탄성률 $\left(\mathrm{G}^{\prime}\right)$ 또한 기존 보고된 $3 \mathrm{D}$ 프린팅 압출형 잉크와 일치하는 $\sim 10^{6}$ 값을 나타낸다. 또한 프린팅 중 용매가 증 발하여 잉크가 굳고 노즐이 막히는 현상을 방지하기 위해 끓는점이 높은 에틸렌글리콜 $\left(197.3{ }^{\circ} \mathrm{C}\right)$ 과 글리세롤 $(290$ $\left.{ }^{\circ} \mathrm{C}\right)$ 을 첨가하여 잉크의 상태를 안정하게 유지하며 프린팅 을 할 수 있음을 보여주었다. 프린팅 후 건조된 전극은 유 기바인더 제거와 입자간의 소결을 위해 $600^{\circ} \mathrm{C}$ 에서 열처 리를 진행하였으며 열처리 후 소결된 전극은 전해액 침투 에 유리한 다공성 형태의 전극을 나타냈다. 8층으로 적층 한 LTO와 LFP는 1 에서 각 $160 \mathrm{mAh} / \mathrm{g}$ 과 $131 \mathrm{mAh} / \mathrm{g}$ 의 용량을 보였다. Fig. 9(c), (d)는 8층에서 16층으로 2 배 적층했으나 단위면적당 용량은 2 배가 되지 않는 방전 특성을 보여 주는데, 이는 electronic transport가 전극 두께에 영향을 받기 때문이라고 밝혔다. 이 연구는 리튬 이온배터리를 $3 \mathrm{D}$ 프린팅에 적용하여 고정밀도의 마이크 로배터리를 제작하는 가능성을 보여주었으나 작동전압 이 낮은 소재인 LTO와 LFP를 활물질로 사용하여 상용전 극과 비교시 에너지밀도가 낮아 고에너지밀도의 구현이 어려우며 $600{ }^{\circ} \mathrm{C}$ 의 열처리과정 포함하여 상용화가 어렵 다는 한계점이 있다.

(a)
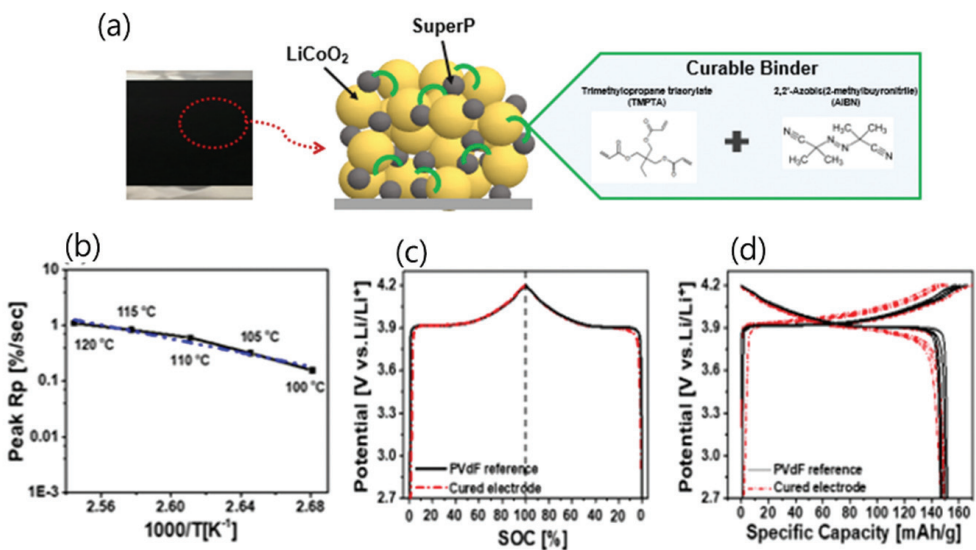

Fig. 10. (a) 경화성바인더를 사용한 3D프린팅용 배터리 모식도 (b) $3 \mathrm{D}$ 프린팅용 배터리 잉크의 전기화학적 특성 


\section{특 집 ㅁㅃ 박수진, 배창준}

최근 국내 재료연구소의 배창준박사 연구진은 $3 \mathrm{D}$ 프린 팅에 적용하기 위한 리튬이차전지 배터리 잉크에 대한 논 문을 발표하였다. ${ }^{14)}$ 이 연구는 소결과정이 요구되지 않을 뿐만 아니라 기존 전극의 상용화 공정과 비교하여 더 낮 은 조건의 열처리를 이용한 공정을 제시하여 상용화에 더 욱 가까운 연구를 보여준다. Fig. 10(a)는 경화성 바인더 를 사용한 $3 \mathrm{D}$ 프린팅용 전극의 모식도를 나타낸다. 이 연 구에서는 기존 상용 바인더인 polyvinylidene fluoride (PVdF)를 아크릴레이트 계열인 Trimethylolpropane triacrylate (TMPTA)로 대체하였다. 경화성 바인더로 사용된 아크릴레이트계 모노머는 빠른 경화속도와 높은 경화밀도를 가지며 특히 TMPTA는 화학적 저항성과 내 수성이 우수한 모노머 중 하나이다. ${ }^{15)} \mathrm{PVdF}$ 를 TMPTA 로 대체함으로써 기존 PVdF를 용해하기 위해 사용되었 던 N-Methyl-2-pyrrolidone (NMP)의 사용량을 감소 시켜 NMP 건조시간과 독성을 줄이고 건조 과정 중 발생 할 수 있는 결함 문제를 방지하였다. ${ }^{16)}$

고정밀도의 전극 제작을 통해 배터리의 성능을 향상시 키기 위해서는 $3 \mathrm{D}$ 프린팅 공정성 확보를 위한 점도분석과 배터리잉크가 경화에 미치는 영향에 대한 이해, 전기화학 적 분석이 요구된다. ${ }^{17)}$

TMPTA를 사용한 잉크는 flow index 0.33으로 압출 형 $3 \mathrm{D}$ 프린터에 적합한 점도 범위를 보였다. 뿐만 아니라 전도재로 사용되는 carbon black이 경화에 있어서 radical scavenger 역할을 하여 경화를 지연 시킴을 시 차열량주사분석을 통해 밝혔다. 배터리 잉크의 경화조건 최적화를 위한 경화개시온도, 경화속도와 경화에 필요한 활성화에너지를 아래의 아레니우스 수식을 통해 제시하 였다. ${ }^{[18]}$ 수식에서의 는 temperature-dependent rate constant, $\mathrm{A}$ 는 pre-exponential factor, $\mathrm{E}$ 는 활성화에 너지, $\mathrm{R}$ 과 $\mathrm{T}$ 는 각각 기체상수와 경화온도를 뜻한다.

$$
\mathrm{K}(\mathrm{T})=\mathrm{A} \cdot \exp \left(\frac{-E}{R T}\right)
$$

Fig. 10(b)는 경화온도에 따른 최대경화속도를 나타낸 그래프이며 이때 기울기는 활성화 에너지 $(\mathrm{E})$ 를 의미하며 $118.9 \mathrm{~kJ} / \mathrm{mol}$ 임을 확인하였다. 활성화 에너지를 기반으 로 경화성 바인더를 포함한 3D 프린팅용 배터리 잉크의
정확한 경화 온도를 계산해 낼 수 있으며, 3D 프린팅 배 터리 제작 시 정교하게 공정 변수를 제어할 수 있으며 더 욱 정밀하게 전극 구조를 제어함으로서 고성능 배터리를 제작할 수 있게 된다.

Fig. 10(c)와 (d)는 상용 바인더인 polyvinylidene fluoride를 이용하여 제작한 기준전극과 $3 \mathrm{D}$ 프린팅용 잉 크로 제작한 전극의 전기화학특성 비교를 나타낸다. 이를 통해 이론용량과 유사한 $147.8 \mathrm{mAh} / \mathrm{g}$ 의 용량을 보였으 며 산화 환원 전위를 비교한 결과 유의미한 차이를 보이 지 않음을 확인하였다.

\section{3. 요약 및 전망}

리튬이온배터리는 대체에너지 가운데 고에너지밀도, 높은 출력, 고수명 등의 여러 이점으로 가장 각광받고 있 는 그린에너지 중 하나이다. 하지만 전기차와 드론과 같 은 고에너지밀도와 고속충전이 요구되는 어플리케이션 에 적용하기 위해 단위면적당 활물질의 로딩을 높여야 하 지만 현재 단순구조 전극의 경우 활물질의 로딩이 높을수 록 전기화학적 성능이 저하되는 한계점이 존재한다.

전극구조 제어는 이러한 문제점을 극복하는 효과적인 해결책으로 3 차원으로 연결된 기공네트워크를 갖는 전 극구조를 적용하여 고에너지밀도와 고속충방전을 구현 하기 위한 연구들이 활발하게 진행되고 있다. 합성을 통 해 템플릿을 제작하고 활물질 증착을 통해 전극구조를 제어하는 방법, 압출공정을 반복하여 리튬이온이동통로 채널을 만드는 방법 외에도 나무와 같은 bio 템플릿을 이 용한 공정 등을 통해 전극구조 제어가 리튬이온확산속도 를 빠른 충방전 속도에서 크게 향상시킬 수 있음을 확인 하였다.

하지만 위의 공정을 통해 제작한 전극 구조는 기존 공 정에 비해 생산성 및 경제성이 저하되어 상용화가 어렵다 는 단점이 있다. $3 \mathrm{D}$ 프린팅 기술의 도입은 이러한 복잡구 조 전극 제작의 한계 극복을 위한 해결책이 될 수 있다. 국내 경제 성장의 원동력 중 하나가 될 것으로 기대를 모 았던 리튬이차전지산업이 일본의 기술력과 중국의 생산 성 사이에서 주춤하고 있는 현 시점에서 $3 \mathrm{D}$ 프린팅 공정 
의 적용으로 전극구조를 설계하고 고에너지밀도, 고속충 방전 배터리를 구현하는 것은 새로운 전환점을 마련할 수 있을 것이다.

\section{참고문헌}

1. J. M. Tarascon, M. Armand, Nature 2001, 414, 359.

2. M. DOYLE , J. NEWMAN Journal of Applied Electrochemistry 1997, 27, 846-856.

3. H. Zheng, J. Li, X. Song, G. Liu, V. S. Battaglia, Electrochimica Acta 2012, 71, 258-265.

4. Z. Du, D. L. Wood, C. Daniel, S. Kalnaus, J. Li, Journal of Applied Electrochemistry 2017, 47, 405415.

5. A. Vu, Y. Qian, A. Stein, Advanced Energy Materials 2012, 2, 1056-1085.

6. J. B. Goodenough, in Lithium Ion Batteries Fundamentals and Performance Wiley-VCH , WeinheimGermany 1998.

7. H. Zhang, X. Yu, P. V. Braun, Nature nanotechnology 2011, 6, 277-281.

8. C.-J. Bae, C. K. Erdonmez, J. W. Halloran, Y.-M. Chiang, Advanced Materials 2013, 25, 1254-1258.

9. G. H. Lee, J. W. Lee, J. I. Choi, S. J. Kim, Y.-H. Kim, J. K. Kang, Advanced Functional Materials

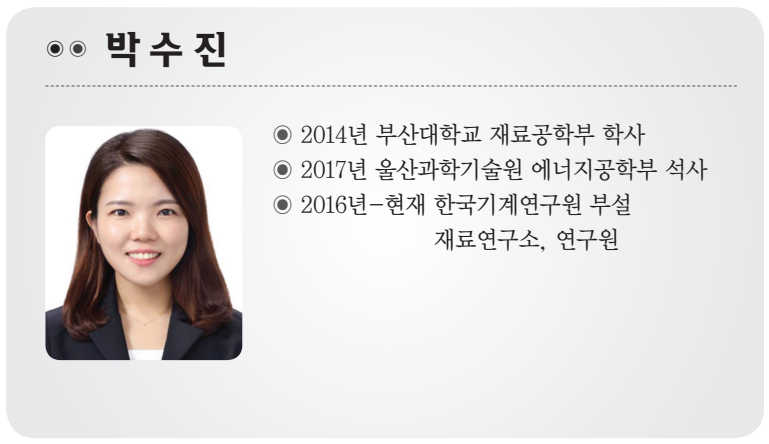

2016, 26, 5139-5148.

10. L. R. F. A. J. Bard, Electrochaemical Methods: Fundamentals and Applications, 2nd ed, Wiley, 2000.

11. aX. Li, T. Fan, Z. Liu, J. Ding, Q. Guo, D. Zhang, Journal of the European Ceramic Society 2006, 26, 3657-3664; bZ. Liu, T. Fan, D. Zhang, Journal of the American Ceramic Society 2006, 89, 662-665.

12. K. Sun, T.-S. Wei, B. Y. Ahn, J. Y. Seo, S. J. Dillon, J. A. Lewis, Advanced Materials 2013, 25, 45394543.

13. C.-J. Bae, A. Ramachandran, K. Chung, S. Park, J. Korean Ceram. Soc 2017, 54, 470-477.

14. S. Park, N. S. Nenov, A. Ramachandran, K. Chung, S. Hoon Lee, J. Yoo, J.-g. Yeo, C.-J. Bae, Energy Technology 2018, 6, 2058-2064.

15. L. E. Schmidt, Y. Leterrier, J.-M. Vesin, M. Wilhelm, J.-A. E. Månson, Macromolecular Materials and Engineering 2005, 290, 1115-1124.

16. K. P. Lee, N. C. Chromey, R. Culik, J. R. Barnes, P. W. Schneider, Fundamental and Applied Toxicology 1987, 9, 222-235.

17. C.-J. Bae, A. B. Diggs, A. Ramachandran, in Additive Manufacturing (Eds.: J. Zhang, Y.-G. Jung), Butterworth-Heinemann, 2018, pp. 181-213.

18. T.-M. G. Chu, J. W. Halloran, Journal of the American Ceramic Society 2000, 83, 2375-2380.

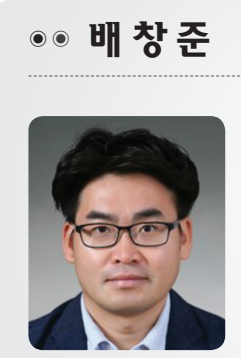

( 2008년 (미국) 미시간 대학교 박사 ○ 2011년 (미국) MIT 박사후 연구원

○ 2016년 (미국) Xerox-PARC, Research Staff

○ 2016년-현재 한국기계연구원 부설 재료연구소, 선임연구원 